\title{
Peran Jenis dan Partisipasi Politik
}

\author{
Thobagus Moh Nu'man \\ Emi Zulaifah \\ Universitas Islam Indonesia
}

\begin{abstract}
Political participation is the activity of private citizens for the purpose of influencing government decision making. Gender role is defined as behavioral predisposition of a person as it relates to his/ her gender. Gender role can be grouped into feminine, masculine androgyny and unclassified. This study is aimed at finding relationship between gender role and political participation among college female activists. The subjects of this study were female students from various university in Yogyakarta, with age ranging from $18-28$ years. Gender role was measured by using gender role scale, modeling one from Bem Sex Role Inventory. Political participation was measured using political participation scale which shows the following indicators: voling activity, organizational participation, political discussion, lobbying and finding connection. The dato was analyzed by one way ANOVA. The results indicated that there are no differences in poltical participation as seen from four different gender roles $(F=1,273 ; P>0,05)$. Practical and research implications are discussed.
\end{abstract}

Key words: Gender role, Polfical participation, Bem's Sex Role Inventory.

\section{PENGANTAR}

$S^{s}$ cara umum, biasanya isu-isu berkaitan dengan persoalan perempuan akan mendapatkan telaah secara khusus di bawah tema jender. Jender sendiri dapat diartikan sebagai sifat yang melekat pada laki-laki dan perempuan yang dikonstruksi secara sosial budaya atau sering disebut kodrat budaya (Setiawati, 2000). Sebutan kodrat budaya ini seringkali me-nimbulkan ketidakadilan jender pada perempuan. Persoalan perempuan, dalam telaah jender, dapat muncul antara lain berkaitan dengan ketidakadilan jender ( $g$ ender inequity). Menurut Fakih (1996), ketidakadilan jender termanifestasikan dalam beberapa hal. Pertama, adanya stereotipe masyarakat dalam memandang citra feminin sebagai perempuan yang ideal. Kedua, beban ganda, yaitu adanya pembagian wilayah kerja domestik untuk perempuan dan wilayah kerja publik untuk laki-laki, sehingga menjadikan beban ganda ketika perempuan pergi ke sektor publik. Ketiga, kekerasan. Banyak kasus kekerasan yang ditemukan seringkali menjadikan perempuan sebagai korban. Keempat, terjadinya marginalisasi, sehingga perempuan menjadi kaum yang terpinggirkan, mereka dianggap sebagai warga masyarakat kelas dua. Kelima, perempuan mengalami subordinasi. 
Isu ke empat, marjinalisasi perempuan. terjadi hampir di segala sektor, mulai dari sektor ekonomi, sosial sampai sektor politik. Marginalisasi perempuan dalam bidang politik terlihat dari kurangnya negara memperhatikan hak-hak politik perempuan dengan sepenuh hati-kalau tidak mau dikatakan mengabaikan. Sikap masyarakat yang belum bisa menerima kedudukan perempuan dalam pospos penting pad a sektor politik juga jug a bisa dijadikan penilaian adanya marginalisasi terhadap perempuan. Perempuan masih menjadi kontroversi ketika mempunyai peran yang besar dalam menentukan kebijakan publik.

Salah satu isu jender dalam politik yang menimbulkan perbincangan kontroversial adalah kemunculan Megawati, yaitu bagimana seorang Megawati - yang notabene seorang perempuan, tiba-tiba menjadi primadona bagi banyak orang di panggung politik, bahkan bersama partai yang dipimpinnya memenangkan pemilu 1999. Kontroversi ini masih berlanjut ketika partainya mencalonkannya menjadi calon presiden Republik Indonesia. Dari sini dapat dilihat betapa masyarakat masih belum bisa menerima kesetaraan, dan masih terjebak dalam persoalan bias jender dalam melihat persoalan besardi sekelilingnya serta dalam memutuskan sesuatu.

Kecenderungan masyarakat untuk menjadi bias jender dapat dipahami bila persoalan itu diletakkan dalam kerangka perkembangan individu, sosialisasi, dan akulturasi (Matsumoto, 1996). Melalui proses yang dijalani sejak lahir inilah pada akhirnya masyarakat akan menentukan peran yang layak diterima seseorang sesuai jenis kelaminnya (penggolongan peran jender). Perlakuan orang tua yang membedakan antara anak laki-laki dan anak perempuan melalui wama selimut atau jenis pakaian memperkuat konsep peran jender pada anak. Kondisi ini melahirkan konsep atau keyakinan tentang sifat pribadi laki-lakl dan perempuan yang disebut stereotipe jenis kelamin (Sears, dkk, 1994). Stereotipe ini memberi gambaran tentang ciri-ciri peran gender tertentu sebagai bagian dari kategori sosial. MenurutAshmore (Sears, dkk. 1994) stereotipe ini dapat dijelaskan dengan membedakannya menjadi dua yaitu, pertama, stereotipe budaya yaitu gambaran berbagai level masyarakat mengenai jenis kelamin. Kedua, stereotipe pribadi, yaitu keyakinan dari individu mengenai ciri-ciri kelompok tertentu.

Pengaruh penggolongan peran jender ini kemudian menciptakan apa yang disebut wilayah publik dan wilayah domestik. Wilayah domestik yaitu kegiatan rumah tangga yang bersifat kewanitaan seperti menyusui, memasak. Wilayah publik adalah lingkungan di luar rumah, dimana laki-laki mendominasi di dalamnya. Wilayah ini mencakup politik, ekonomi, kegiatan keagamaan, dan kegiatan di tuar rumah lainnya. Tugas perempuan hanyalah di wilayah domestik bukan d wilayah publik. Perempuan yang mengambil peran dalam panggung politik dianggap menyalahi kodrat dan dianggap tabu, karena tidak sesuai dengan peran jendernya. Politik seolah-olah hanya milik laki-laki. Politik dan perilaku politik dipandang sebagai aktivitas maskulin (Cantor dan Bernay, 1998). Politik kotor, jahat, manipulatif, kejam, sehingga politik dipandang tidak cocok dengan kaum perempuan (Wardani, 2000).

Salah satu indikator tingkat partisipasi politik perempuan dapat dilihat dari keterwakilanm perempuan dalam legislatif dan parlemen. Dari waktu ke waktu statistik keterlibatan perempuan di seluruh dunia khususnya di parlemen masih fluktuatif sifatnya. Pada tahun 1988, data menunjukkan 14,8 persen kursi DPR diduduki perempuan. Prosentase ini kemudian menurun menjadi 11,3 persen pada tahun 1995. namun pada tahun 2000 prosentase keterlibatan perempuan di parlemen meningkat drastis (Wardani, 2000).

Rata-rata jumlah perempuan negaranegara asia yang duduk di parlemen berkisar antara $5-15 \%$. Di Indonesia sendiri, jumlah perempuan di partemen hasil pemilu 1999 mencapai $8 \%$ ( 40 orang dari 500 kursi). Hal ini merupakan sebuah ironi mengingat $51 \%$ 
dari total penduduk Indonesia adalah perempuan dan jumlah pernilih perempuan dalam pemilu 1999 adalah $51-57 \%$. Pencapaian 8 $\%$ ini menunjukkan adanya penurunan jumlah dibandingkan jumlah perempuan di parlemen pada tahun 1995 yang mencapai $12,2 \%$. Berdasarkan data Panitia Pemilihan Indonesia (PPI)yang dilaporkan oleh Kompas (10/6/ 1999) bahwa daftar calon tetap (DCT) berkelamin perempuan dari 48 partai politik yang ikut Pemilihan Umum 1999 berjumlah sekitar 1.398 dari 11.095 DCT keseluruhan $(12,6 \%)$, bahkan hanya $4,3 \%$ berada di urutan nomor t-5.

Di era reformasi, yang điyakini sebagai era kebebasan, peran perempuan dalam panggung politik mulai mendapat angin segar. Hal ini dapat dilihat dari mulai dibukanya kesempatan bagi perempuan untuk berperan secara luas di segala bidang, khususnya di bidang politik yang selama iri masih dianggap tabu bagi perempuan. Berdirinya LSM-LSM, semaraknya Pusal Studi Wanita (PSW) di bawah perguruan tinggi, yang melakukan advokasi dan pemberdayaan (empowerment) terhadap perempuan adalah beberapa buktinya. Hal ini juga diikuti dengan redefiniși perempuan dalam GBHN, yang bukan curna berfungsi sebagi istri dan ibu. Disamping itu, digantinya nama Menteri Peranan Wanita menjadi Menteri Peranan Perempuan memberi konsekuensi arti yang lebih luas terhadap peran dan posisi perempuan. Perkembangan terakhir menunjukkan bahwa kini Indonesia menetapkan kuota bagi keterwakilan perempuan dalam DPR/MPR, hingga paling tidak $30 \%$ dari keseluruhan anggota lembaga perwakilan tersebut.

Kondisi ini melahirkan berbagai sikap. ada yang responsif dengan kondisi ini kemudian mengambil peran di dalamnya. Namun demikian, tidak sedikit perempuan yang masih takut-takut dengan dunia politik, baik politik dalam arti yang luas maupun yang sempit. Politik masih menjadi momok bagi kaum perempuan. Banyaknya organisasi perempuan dan pergerakan-pergerakan serta LSM-LSM pernbela perempuan adalah faktor signifikan dan menunjukkan pengaruhnya terhadap perilaku politik perempuan. Hal ini ditegaskan olehAmwar (dalam RCTI 25/4/2000) bahwa organisasi-organisasi perempuan merupakan wadah yang strategis untuk mengasah kemampuan berdiskusi kaum perempuan terutama untuk menghadapi forum-forum besar di sektor publik. Maraknya upaya mengangkak partisipasi perempuan, belum diikuti dengan penelitian yang mengkaji sejauh mana partisipasi politik itu memang mendapatkan tempatnya di kalangan perempuan sendiri. Selain itu, penelitian tentang apakah keinginan berpartisipasi memang ditentukan oleh peran jenis yang dihayati, sebagai sebuah variabel psikologis, sejauh ini belum mendapattkan kajian empirik yang memadahi.

\section{TINJAUAN PUSTAKA}

Huntington dan Nelson (1994) mendefinisikan partisipasi politik sebagai kegiatan warga negara biasa (private cilizen) yang bertujuan mempengaruhi pengambilan keputusan pemerintah. Dari definisi ini Huntington dan Nelson (1994) memberi catatan akan beberapa aspek yang perlu diperhatikan. Portama, partisipasi politik mencakup kegiatankegiatan, bukan sikap. Attinya, bahwa partisipasi politik bukanlah identik dengan orientasi warga negara terhadap politik. Kedua, partisipasi polkik adalah kegiatan politik warga negara biasa atau perorangan dalam peranan mereka sebagai warga negara biasa. Di sini terlihat garis batas antara partisipasi politik warga negara biasa dengan orang-orang profesional di bidang politik. Ketiga, kegiatan yang dimaksudkan di sini adalah kegiatan yang dimaksudkan untuk mempengaruhi pengambilan keputusan pemerintah. Keempat, semua kegiatan yang dimaksudkan untuk mempengaruhi pemerintah, tak peduli apakah kegiatan itu benar-benar mempunyai efek itu. Artinya, apakah kegiatan itu mempunyai tingkat keberhasilan ataupun tidak, tetap dinamakan partisipasi politik. Lebih lanjut, Huntington dan Nelson (1994) mengkategorikan partisipasi politik menjadi dua yaitu partisipasi yang bersifat otonom dan patisjpasi yang dimobilisasi. Meskipun begitu peng- 
kategorian ini bukan kemudian bersifatdikotomis yang dapat dibedakan secara tajam.

Tidak berbeda dengan apa yang telah didefinisikan oleh Huntington dan Nelson mengenai partisipasi politik, Haricahyono (1986) mengartikan partisipasi politik sebagai usaha terorganisir dari warga negara untuk mempengaruhi bentuk dan jalannya kebijaksanaan umum pemerintah. Akan tetapi, definisi yang kedua tidak memasukkan mobilisasi sebagai partisipasi politik. Batasan ini diperkuat oleh Surbakti (1992) yang mendefinisikan partisipasi politik sebagai keikutsertaan warga negara biasa (yang tidak mempunyai kewenangan) dalam mempengaruhi proses pembuatan dan pelaksanaan keputusan politik. Lebih lanjut, Surbakti (1992) menjelaskan bahwa kegiatan warga negara biasa ini pada dasarnya dibagi dua, yakni mempengaruhi isi kebijakan umum dan ikut menentukan pembuat dan pelaksana keputusan politik. Dari definisi ini tersirat adanya penegasan bahwa partisipasi politik itu berarti keikutsertaan warga negara biasa dalam menentukan segala keputusan yang menyangkut atau mempengaruhi hidupnya.

Referensi atau bentuk-bentuk partisipasi politik dapat dijelaskan sebagai berikut:

\section{a. Kegiatan pemilihan}

Termasuk di dalamnya yaitu pemberian suara (Voting) yang merupakan bentuk partisipasi politik yang paling umum dan sudah sejak lama dikenal dalam sebuah pemerintahan. Bentuk ini bișa ditemukan hampirdi seluruh negara di belahan dunia. Dapat dikalakan pemungutan suara ini sifatnyajauh lebih meluas dibandingkan dengan bentukbentuk partisipasi lainnya.

Disariping pemberian suara atau pemungutan suara, yang terkaitdengan kegialan pemilihan adalah kegiatan kampanye. Kegiatan kampanye ini dilakukan sebelum pelaksanaan pemberian suara. Secara kualitas, menurut Haricahyono (1986) di dalam kegiatan kampanye terdapat dua kelompok yaitu kelompok mayorilas yang kegiatannya terbatas pada ikut-ikutan saja tanpa didasari kejernihan berpikir serta strategi tertentu.
Kelompok kedua yaitu, Kelompok minoritas yang selain aktif dalam kegiatan kampanye juga berperan sebagai penggerak atau motornya.

Lebih luas lagi, kegiatan pemilitan menurut Huntington dan Nelson (1994) mencakup sumbangan-sumbangan untuk kampanye, bekerja dalam suatu pemilihan, mencari dukungan bagi seorang calon, atau tindakan yang bertujuan mempengaruhi hasil proses pemilihan.

\section{b. Kegiatan organisasi}

Kegiatan ini menyangkut partisipasi seorang anggota atau pejabat dalam suatu organisasi yang mempunyai tujuan utama dan eksplisit untuk mempengaruhi pengambilan keputusan pemerintah. Termasuk dalam kegiatan ini adalah masuk ke dalam kelompok kepentingan. Seorang individu yang hanya masuk ke dalam sebuah organisasi atau kelompok kepentingan tanpa dia melakukan aktivitas organisasi sudah dapat dikatakan berpartisipasi (Huntington dan Nelson, 1994).

\section{c. Diskusi politik}

Suatu kegiatan yang dilakukan oleh warga negara untuk membicarakan persoalanpersoalan poltik yang terjadi di negaranya. Diskusi ini juga mencoba merumuskan alternatif pemecahan persoalan-persoalan tersebut. Hasil dari diskusi ini bisa jadi kemudian direkomendasikan kepada pemerintah namun hal ini tidak mengikat pihak penguasa,

\section{d. Melakukan Lobi}

Kegiatan ini berupa upaya-upaya dari perorangan atau kelompok-kelompok untuk menghubungi pejabat-pejabat pemerintah dan pemimpin-pemimpin politik dengan tujuan untuk mempengaruhi keputusan yang menyangkut banyak orang atau keputusankeputusan politik yang menyangkut publik. Huntington dan Nelson (1994) menyebutkan kegiatan-kegiatan yang termasuk lobbying yaitu melakukan pemogokan yang tertib atau melakukan demonstrasi. 


\section{e. Mencari koneksi (contacting)}

Tindakan perorangan untuk berhubungan dengan pejabat-pejabat pemerintah yang dimaksudkan untuk memperoleh manfaat bagi hanya satu atau segelintir orang.

\section{f. Tindakan kekerasan (Violence)}

Merupakan tindakan yang bertujuan untuk mempengaruhi pengambilan keputusan pemerintah dengan jalan menimbulkan kerugian fisik terhadap orang-orang atau harta benda. Contoh dari tindakan kekerasan itu antara lain : kudeta, pembunuhan politik, kekerasan politik (political violence), huru hara, pemberontakan dan revolusi.

Surbakti (1992) mengungkapkan faktorfaktor yang mempengaruhi tinggi rendahnya partisipasi politik seseorang, ialah kesadaran politik đan kepercayaan kepada pemerintah. Kesadaran politik ini terkait dengan kesadaran akan hak dan kewajban sebagai warga negara, mencakup sampai sejauhmana pengetahuan dan minat seseorang serta perhatiannya terhadap lingkungan masyarakat dan politik tempat ia berada. Kesadaran politik inipun tidak bisa dilepaskan dari internalisasi nilai-nilai yang berlaku of dalam masyarakat individu tersebut. Kepercayaan terhadap pemerintah lebih terkait pada penllaian individu terhadap pemerintahan yang ada. Apakah pemerintah dapat dipercaya dan dapat dipengaruhi atau tidak.

Kedua hal tersebut di atas sejalan dengan apa yang dikatakan oleh Haricahyono (1986) bahwa dalam menilai tingkat partisipasi politik dapat menggunakan dua tolok ukur. Pertama, pengetahuan đan penghayatan terhadap politik yang dimiliki oleh individu, antara lain tentang hak dan kewajiban seseorang sebagai warga negara. Untuk yang memiliki pengetahuan dan penghayatan yang tinggi terhadap politik dimungkinkan akan mampu berpartisipasi secara aktif dan rasional. Kөdua, kepercayaan masyarakat terhadap sistem politik yang berlaku. Hal ini ditentukan oleh kemampuan sistem politik dalam menjawab tuntutantuntutan yang wajar dari masyarakat secara memuaskan,

\section{Peranjenis}

Peran jenis điartikan sebagai perilaku atau kepribadian yang ditentukan oleh jenis kelamin, yang dibedakan atas tipe feminin dan tipe maskulin (Whitley dan Bernard, 1983). Eysenck (Nuryoto, 1991) menyatakan bahwa peran jenis adalah perilaku yang spesifik yang diharapkan dan sebagai standar yang diterapkan pada laki-laki dan perempuan, kalau terjadi penyimpangan subjek dianggap negatif. Menurut D' Andrade (Nuryoto, 1991) peran jenis adalah suatu sifat yang sebenamya dapat dipelajari untuk meningkatkan aktivitas yang sesuai dengan harapan masyarakat, tanpa memperhatikan jenis kelaminnya. Harapan dan budaya masyarakat sangat berperan dalam pembentukan peran jenis seorang individu. Hurlock (Nuryoto, 1981) menyatakan bahwa belajar melakukan peran jenis relatif lebih sulit dibandingkan dengan belajar bergaul dengan teman sebaya baik sejenis maupun lawan jenis. Menurut Nuryoto (1991), pada umumnya proses mempelajari peran jenis Ini akan lebih mudah terjadi pada anak laki-laki, dibandingkan anak perempuan. Sebagai sebuah hal yang dipelajari lewat proses sosialisasi, maka peran jenis dengan sendirinya akan membudaya. Dimana sesuatu yang diperankan oleh laki-laki dan perempuan dalam peran jenisnya mempunyai perbedaan. Aktivitas laki-laki seringkali digambarkan dengan keper-kasaan, seperti berburu, pembuat kapal. Sedangkan perempuan digambarkan dengan kelembutan seperti mengasuh anak, memasak, kerja rumah tangga. Hal ini tidak terlepas dari pemahaman masyarakat. Sebagaiman yang dikemukakan oleh Matsumoto (1996), Dali (1982), Rogers (1977), peranjenis adalah perilaku, sikap-sikap peranan-peranan sosial yang oleh masyarakat kebudayaan tertentu dianggap cocok untuk jenls kelamin tertentu. Pembentukan peran jenis dapat dijelaskan melaui empat teori (Abott, 992). Pertama, teori identifikasi. Pendekatan ini didasarkan pada Psikoanalisa Freud. Peranjenis, Menurut teori ini, dipelajari anak lewat lingkungan sekitarnya. Anak 
melakukan identifikasi terhadap pertakuan orang tuanya. Anak laki-laki mengidentifikasi peran jenisnya lewat perlakuan ayahnya sehingga dia mengerti perilaku seorang lakilaki. Sedangkan anak perempuan akan mengidentifikasi perlakuan ibunya sebagai peran jenis yang dimiliki oleh seorang perempuan.

Kedua, teori pembentukan peran jenis yang didasarkan pada tekanan sosial. Menurut teori ini, anak belajar peran jenis dari lingkungan sosial yang dominan. Seorang individu dalam berperilaku didasarkan pada nilai-nilai yang berkembang di masyarakatnya. Apa yang dinilai benar atau salah dan apa yang dinilai baik atau buruk oleh masyarakat sekitamya. Tekanan sosial dan pembiasaan lewat nilai-nilai yang berkembang ini yang berlangsung terus menerus mengakibatkan terbentuknya pola dan perilaku yang sesuai dengan harapan masyarakat, termasuk perilaku yang sesua dengan jenis kelaminnya.

Ketiga, teori pembentukan peran jenis yang didasarkan pada perkembangan kognitif. Pendekatan ini menekankan adanya peran aktif individu. Individu dipandang sebagai seorang yang aktif dan dinamis serta mempunyai kemampuan berikir. Individu memiliki kemampuan untuk menentukan apa yang mesti dilakukan. Kemampuan ini didukung oleh pengetahuan sebagai hasil dari proses berpikir terutama pengetahuan tentang atternatif berperilaku sehingga individu dapat menentukan bagaimana seharusnya ia berperilaku sesuai dengan jenis kelaminnya.

Keempat, teori skema jender yang merupakan kombinasi antara teori tekanan sosial dan teori perkembangan kognitif. Teori ini dikembangkan oleh Bem (Abott, 1992) yang menyatakan bahwa skema jender merupakan sejumlah persepsi individu terhadap atributatribut dari perilaku jenis kelamin pria dan wanita. Menurut Bem (Kuwato, 1992), individu dengan kematangan kognitifnya aktif metakukan seleksi terhadap sifat-sifat kepribadian manusia, baik pria maupun wanita. Selain itu dengan kemauan dan kemampuan untuk berpikir selektif individu akan memilih perkembangan yang sesuai dengan ke- inginannya. Selanjutnya, tipe-tipe peran jenis dapat dikategorikan menjadi empat yaitu: Kewanitaan (feminin), kepriaan (maskulin), androgini dan tak terbedakan (undifferenti$a t e d)$. Peran jenis ini akan menunjukkan pola serupa bila dipakai untuk melihat kelompok jenis kelamin yang berbeda. Artinya baik lakilaki maupun perempuan, akan memiliki penghayatan yang serupa akan peran yang sesuai dengan jenisnya. Laki-laki dengan demikian bisa memiliki peran jenis yang cenderung feminin, sedangkan perempuan dapat juga memiliki peran jenis yang cenderung maskulin.

Berkaitan dengan partisipasi politik di kalangan perempuan, adanya pendapat bahwa politik adalah sesuatu yang lebih cocok digeluti dan ditekuni laki-laki, akan lebih ditunjukkan oleh mereka yang cenderung maskulin. Dengan demikian, untuk sementara dapat diduga bahwa mereka yang memiliki peran jenis maskulin akan cenderung memiliki partisipasi politik yang lebih tinggi.

\section{HIPOTESIS}

Ada perbedaan tingkat partisipasi politik berdasarkan peran jenis androgini, maskulin, dan feminin. Individu yang berperan jenis maskulin akan lebih berpartisipasi politik daripada individu berperan jenis feminin, androgini dan tak terbedakan.

\section{METODE PENELITIAN}

\section{Variabel Penelitian}

Penelitian ini mengajukan peran jenis sebagai variabel bebas dan partisipasi politik sebagai variabel tergantung. Peran jenis adalan seperangkat pola perilaku individu yang didasarkan pada kesadaran jenis kelamin dan disesuaikan dengan harapan serta norma masyarakat. Pe ran jenis digolongkan menjadi empat kategori, yaitu feminin, maskulin, androgini dan tak terbedakan. Dalam 
penelitian ini peran jenis akan diukur dengan skala peran jenis yang dikembangkan berdasar Bem's Sex Role Inventory.

Partisipasi politik adalah usaha atau kegiatan atau perilaku dari warga negara biasa (private citizen), bukan profesional di bidang politik, yang bisa diamati dan bertujuan untuk mempengaruhi peng-ambilan keputusan, bentuk dan jalannya kebijaksanaan umum pemerintah dimana perilaku itu daiam bentuk atau pola kegiatan pemilihan, kegiatan berorganisasi, diskusi politik, lobbying, dan mencari koneksi. Dalam penelitian ini aspek melakukan tindak kekerasan tidak dimasukkan dalam pengukuran, mengingat hal ini bisa jadi kurang relevan dengan konteks subjek yang diteliti. Partisipasi itu sendiri dapat bersifat spontan, secara sinambung atau sporadis, efektif atau tidak efektif. Partisipasi politik dalam penelitian ini dilihat dengan angket partisipasi politik yang disusun oleh peneliti.

\section{Subjek Penetitian}

Subjek dalam penelitian ini adalah Mahasiswi yang aktif di organisasi-organisasi kemahasiswaan ekstra-kampus yang ada di Yogyakarta. Berusia antara 18 hingga 28 tahun.

\section{Metode Analisis Data}

Analisis tentang perbedaan partisipasi politik yang didasarkan pada peran jenis dilakukan dengan AnalisisVarian (Anava) satu jakur.

\section{HASIL PENELITIAN}

Berdasarkan hasil uj Anava satu jalur yang dilakukan tehadap partisipasi politik dan peran jenis, diketahui bahwa tidak ada perbedaan tingkat partisipasi politik berdasrkan pada peran jenis $(F=1,273 ; P=$ $0,269)$. Jadi Hipotesis penelitian ini tidakdapat diterima.
Dari hasil uji hipotesis diketahui bahwa tidak ada perbedaan tingkat partisipasi politik yang signifikan antara peran jenis yang ada. Meski demikian ada hal yang patut untuk diketengahkan sebagai tambahan analisis lebih lanjut. Dari fakta yang ada ditemukan bahwa peran jenis androgini memiliki skor rerata yang paling tinggi $(93,714)$, sedangkan skor rerata urutan kedua ditempati peran jenis maskulin (93,667), kemudian disusul peran jenis tak tergolongkan $(84,071)$, dan terakhir adalah peran jenis feminin $(82,00)$.

\section{PEMBAHASAN}

Meskipun tidak ada perbedaan tingkat partisipasi politik yang berdasar peran jenis, secara deskriptif dengan melihat hasil dari skor rerata yang ada, terlihat bahwa peran jenis androgini lebih menunjukkan adanya partisipasi politik, sedangkan peran jenis feminin boleh dikatakan tingkat partisispasi politiknya rendah. Peranjenis maskulln, meskipun skor reratanya di bawah peran jenis androgini, masih dapatdikatakan menunjukkan adanya partisipasi politik yang sedang.

Berdasarkan dari pertanyaan terbuka yang diajukan, memang tidak ditemukan adanya perbedaan yang mencolok antar peran jenis dalam partisipasi politiknya, meskipun ada aspek-aspek tertentu yang menarik untuk dicermati. Dalam hal tujuan untuk masuk ke organisasi, maka mereka yang menghayati peran jenis maskulin lebih banyak yang memilih "membuka atau mencari akses politik" daripada mereka yang menghayati peran jenis lainnya. Aspek lain adalah tentang keteribatannya dalam aksi massa, menunjukkan tidak satupun peran jenis feminin yang terlibat sobagai orator, Hal ini mengindikasikan masih segannya peran jenis femin|n untuk berhadapan dengan banyak orang.

Tidak adanya perbedaan partisipasi politik dilihat dari peran jenis bisa dijelaskan dari beberapa hai berikut. Pertama, ada kemungkinan kesadaran politik di kalangan perempuan memang pada dasarnya masih 
belum terlalu tinggi, tanpa memandang peran jenis yang dihayatinya. Artinya, bahkan di kalangan perempuan yang cenderung maskulin, mungkin masih ada ketidakmampuan menerima kegiatan-kegiatan yang selama ini dipandang secara tradisional sebagai bagian dari wilayah kehidupan laki-laki. Kedua, hal yang sebaliknya bisa juga terjadi. Kesadaran perempuan akan hak-haknya, secara umum, tanpa melihat penghayatan akan peran jenis mereka, bisa juga mempengaruhi tidak adanya perbedaan dalam tingkat partisipasi politiknya.

Kedua hat tersebut, secara umum menyiratkan bahwa partisipasi politik ditentukan pertama-tama oleh faktor yang lebih bersifat makro, daripada mikro-individual. Bila hal ini yang terjadi, maka upaya menimbulkan kesadaran poitik yang setara di kalangan lakilaki dan perempuan akan makin berat. Karena hal ini mungkin tidak lagi ditentukan oleh faktor-faktor pada level individu, tapi bisajadi melibatkan sistem yang lebih has. Manakala diskusi tentang partisipasi politik yang lebih mewakili keragaman jender dimunculkan, maka aspek soslalisasi politik dan kebudayaan politik (political culture) dapat dimasukkan dalam analisis. Bagaimana seharusnya masing-masing anggota masyarakat berpartisipasi dalarm sistem politiknya dibentuk oleh nilai-nilai politik yang ada. Terbentuknya nilai-nilai politik ini didasarkan pada proses sosialissasi politik yang ada. Nilainilai politik ini biasanya berkaitan dengan nilainilai sosial, budaya dan agama.

Kebudayaan politik, oleh Kantaprawira (Haricahyono, 1986) diartikan sebagai pola tingkah laku seseorang beserta orientasinya mengenai kehidupan politik dalam suatu sistem politik. Dengan demikian, semakin jelas bahwa partisipasi politik seseorang akan dituntun ofeh budaya politik yang diyakininya. Sejauh budaya politik yang ada memang tidak memberikan kesempatan yang sama terhadap perempuan, maka peran politik di kalangan perempuan pun akan terminimalkan. Perkembangan akhir-akhir ini. untuk lebih mendorong meningkatnya partisipasi pe- rempuan di dunia politik, diharapkan akan menjadi strategi yang positif bagi berubahnya budaya politik di tanah air yang selama beberapa dekade terakhir cenderung didominasi laki-laki. Sebagai sebuah kelompok yang besar, sudah selayaknya perempuan menyuarakan kepedulian, berkaitan dengan hajat hidup mereka, melaui partisipasi politik.

Diskusi partisipasi politik perempuan juga akan menarik bila diarahkan pada kelompok Muslim, kelompok mayoritas bangsa ini. Keterlibatan perempuan di dunia politik di kalangan Islam masih menjadi kontroversi dan perdebatan yang panjang. Masih banyak teks-teks suci yang dijadikan landasan untuk depolitisasi kaum perempuan. Hadist yang sering kali dijadikan rujukan masalah tidak bolehnya perempuan terlibat dalam politik adalah hadist riwayatAl-Bukhari yang menyebutkan, bahwa mereka yang mempercayakan urusan-urusannya kepada perempuan tidak akan pernah merasakan kemakmuran. Bagi kalangan feminis Islam, hadist ini termasuk hadist yang misoginis (antiperempuan) dan perlu dikaji lagi (Mernisi, 1997). Kaum feminis Islam juga menyodorkan fakla bahwa dalam sejarah Isłam perempuan terlibat dalam hal politik bukanlah hat baru. Kenyataan ini ada pada diri 'Aisyah, istri Rasuluflah SAW, yang terlibat dalam perang unta sebagai pemimpin. Dalam kalangan kaum femininis islam, keterlibatan 'Aisyah termasuk keteribatan dalam persoalan politik. Keselaraan laki-laki dan perempuan juga ditunjukkan dalam al-Qur'an surat al-Ahzab ayat 35 , yang mengatakan bahwa Allah akan memberi ampunan dan pahala sesuai dengan apa yang diperbuatnya bagi laki-laki dan perempuan tanpa mem-bedakannya.

Mengingat persoalan politk adalah hal yang sangat penting dalam kaitannya dengan keadilan bagi hak-hak individu, sangat perlu untuk dilakukan upaya membangun politik yang sensitif secara jender (gender sensitive) dan politik yang berperspektif jender.

Kesimpulan dari penelitian ini adalah tidak ada perbedaan tingkat partisipasi pilitik perempuan dilihat dari peran jenis yang 
dihayati. Penelitian ini merupakan langkah konkret untuk memperkaya khazanah keilmuan yang berkaitan dengan persoalanpersoalan jender. Untuk itu, kajian ini tidak berhenti sampai di sini, tetapi masih periu dikembangkan dan dikaji lebih mendalam lagi untuk mendapatkan gambaran dan hasil yang lebih nyata tentang persoalan jender yang terkait dengan politik pada khususnya.

Saran yang dapat dijadikan pertimbangan dalam penelitian yang selanjutnya adalah penelitian diarahkan kepada subjek yang benar-benar terlibat dalam proses politik secara rili, yaitu perempuan yang aktif di partai politik. Hal ini dapat dilakukan dengan, misalnya, menguak lebih jauh lagi profil individu yang memiliki tingkat partisipasi politik yang tinggi, mengeksplorasi kekhasan individual di luar peran jenis yang membedakan mereka dari kelompok perempuan yang lain.

\section{DAFT.AR PUSTAKA}

Abotttt, A.R. 1992. Masculine and Feminine. 2nd Edition. New York: Mc Graw Hill, inc.

Cantor, W.d. \& Bernay, T. 1998. Women in Power. Diterjemahkan ke dalam Bahasa indonesia oleh Abraham RAP. Jakarta: P.T Gramedia.

Dali, G 1982. Kamus Psikologi. Bandung : Tonis.

Fakih, M. 1996. Analisis Gender dan Transformasi Sosial. Yogyakarta : Pustaka Pelajar.

Haricahyono, C. 1986. Ilmu Politik dan Porspektifnya. Yogyakarta : Tiara Wacana dan YP2 LPM.

Huntington, S.P., Nelson, J. 1994. Partisipasi Politik di Negara Berkembang. Jakarta : Rineka Cipta.
Kuwato, T. 1992. Peranan Peran Jenis Terhadap Kreativitas Siswa SMA. Disertasi (tidak diterbitkan). Yogyakarta: Fakultas Psikologi UGM.

1999. Partisipasi setengah Hati. Harian Kompas, 10 Juni 1999.

1999. Masih Dibayangi Bias Gender. Harian Kompas, 10 Juni 1999. 1999. Harus Terus digerakkan, Penyadaran Politik Perempuan. Harian Kompas, 10 Juni 1999.

Matsumoto, D. 1996. Culture and Psychology. Brooks/Cole Publishing Company.

Mernisi, F. 1997. Menengok Kontroversi Peran Wanita dalam Politik. Surabaya : Dunia IImu.

Nuryoto, S. 1991. Perkembangan Kemandirian Remaja Ditinjau dari Tahap Perkembangan dan Peran Jenis. Disertasi (tidak diterbitkan). Yogyakarta: Fakultas Psikologi UGM.

RCTI, Reposisi Perempuan dalam Panggung Poltik. Aneka Dialog. Selasa, 25April 2000.

Rogers, D. 1977. The Psychology of Adolescence, 3 rd -ed. Prentice-Hall Inc., Englewood Cliffs. New Jersey.

Sears, D.O., \& Peplau. 1994. Psikologi Sosial 2 Jakarta: Penerbit Erlangga.

Setiawati, T. 2000. Kajian Perempuan dan Jender. Makalah pada Pelatihan Metode Penelitian berperspektif Jender bagi Dosen Muda PSW. Lembaga Penelitian UII (11/10/2000). Yogyakarta.

Surbakti, R. 1992. Memahami /lmu Politik. Jakarta : Grasindo. 
Wardani, S.B.E 2000. Perempuan dan Kekuasaan Politik : Antara Stigma dan Kemampuan dalam Perempuan dan Kekuasaan. Jakarta : PB Korp PMII Putri.
Whitley, B.E.Jr., \& Bernard. 1983. Sex Role Orientation and Self Esteem : A Critical Meta Analytic Review. Journal of Personality and Social Psychology. No.4, 765-776. Wolf, N. Gegar Gender. Yogyakarta : Pustaka Semesta Press.

$\operatorname{ros} c \cos \cos c o s$ 